\title{
Reliability of a Visual Recognition System for Detection of Johnsongrass (Sorghum halepense) in Corn
}

\author{
Authors: Andújar, Dionisio, Ribeiro, Ángela, Fernández-Quintanilla, \\ Cesar, and Dorado, José
}

Source: Weed Technology, 25(4) : 645-651

Published By: Weed Science Society of America

URL: https://doi.org/10.1614/WT-D-10-00082.1

BioOne Complete (complete.BioOne.org) is a full-text database of 200 subscribed and open-access titles in the biological, ecological, and environmental sciences published by nonprofit societies, associations, museums, institutions, and presses.

Your use of this PDF, the BioOne Complete website, and all posted and associated content indicates your acceptance of BioOne's Terms of Use, available at www.bioone.org/terms-of-use.

Usage of BioOne Complete content is strictly limited to personal, educational, and non - commercial use. Commercial inquiries or rights and permissions requests should be directed to the individual publisher as copyright holder.

BioOne sees sustainable scholarly publishing as an inherently collaborative enterprise connecting authors, nonprofit publishers, academic institutions, research libraries, and research funders in the common goal of maximizing access to critical research. 


\title{
Weed Management-Techniques
}

\section{Reliability of a Visual Recognition System for Detection of Johnsongrass (Sorghum halepense) in Corn}

\author{
Dionisio Andújar, Ángela Ribeiro, Cesar Fernández-Quintanilla, and José Dorado*
}

\begin{abstract}
The feasibility of visual detection of weeds for map-based patch spraying systems needs to be assessed for use in large-scale cropping systems. The main objective of this research was to evaluate the reliability and profitability of using maps of Johnsongrass patches constructed at harvest to predict spatial distribution of weeds during the next cropping season. Johnsongrass patches visually were assessed from the cabin of a combine harvester in three corn fields and were compared with maps obtained in the subsequent year prior to postemergence herbicide application. There was a good correlation ( $71 \%$ on average) between the position of Johnsongrass patches on the two maps (fall vs. spring). The highest correlation (82\%) was obtained with relatively large infestations, whereas the lowest $(58 \%)$ was obtained when the infested area was smaller. Although the relative positions of the patches remained almost unchanged from $1 \mathrm{yr}$ to the next, the infested area increased in all fields during the 4-yr experimental period. According to our estimates, using a strategy based on spraying full rates of herbicides to patches recorded in the map generated in the previous fall resulted in higher net returns than spraying the whole field, either at full or half rate. This sitespecific strategy resulted in an average $65 \%$ reduction in the volume of herbicide applied to control this weed.
\end{abstract}

Nomenclature: Johnsongrass, Sorghum halepense (L.) Pers. SORHA; corn, Zea mays L.

Key words: Weed maps, visual estimation, patchy weed distribution, patch spraying.

La viabilidad de la detección visual de malezas para su tratamiento localizado en base a mapas debe ser evaluada de cara a su aplicación en sistemas de cultivo a gran escala. El objetivo principal de esta investigación fue evaluar la frabilidad y rentabilidad del uso de mapas de rodales de Sorghum halepense elaborados durante la recolección en otoño para predecir la distribución espacial de la maleza en la siguiente campaña de cultivo. Los rodales de $S$. halepense fueron localizados de forma visual desde la cabina de una cosechadora en tres campos de maíz, y su posición se comparó con la de los mapas obtenidos la primavera siguiente, antes del tratamiento de post-emergencia. Los resultados mostraron una buena correlación (71\% en promedio) de la ubicación de los rodales de la maleza entre los dos mapas (otoño vs. primavera). La mayor correlación (82\%) se observó con infestaciones relativamente grandes, mientras que la menor $(58 \%)$ se obtuvo cuando el área infestada era más pequeña. Aunque las posiciones relativas de los rodales se mantuvieron constantes de un año al otro, el área infestada se incrementó en todos los campos durante los cuatro años del período experimental. Según nuestras estimaciones, la estrategia basada en aplicar una dosis completa de herbicida a los rodales localizados el otoño del año anterior produjo un beneficio neto mayor que la aplicación de herbicida sobre todo el campo, ya sea a dosis completa o a mitad de dosis. Esta estrategia de tratamiento localizado resultó en una reducción media del $65 \%$ respecto al volumen de herbicida aplicado en toda la superficie para el control de esta maleza.

Johnsongrass is one of the most important weed species infesting corn fields in North and South America and in southern Europe (Holm et al. 1977) and can greatly reduce corn yields. Bendixen (1986), in North America, reported yield losses up to $100 \%$ in a continuous corn system with high Johnsongrass densities. Studies conducted in Greece, under similar conditions to those present in Spain, showed that corn yields were reduced $83 \%$ and $62 \%$ with season-long interference by Johnsongrass from rhizomes and from seeds, respectively (Mitskas et al. 2003).

The life cycle of Johnsongrass is conducive to its survival in a wide range of environmental conditions. Growth begins from the apical and axillary nodes as well as the primary rhizomes as the temperature increases in the spring. Seedlings emerge later and grow slower than rhizome sprouts (Warwick and Black 1983). Although hundreds of seeds are produced on each panicle, sexual reproduction is not as important as

* First, third, and fourth authors: Graduate Research Assistant, Research Professor, and Staff Scientist, Instituto de Ciencias Agrarias, CSIC, Serrano 115B, 28006 Madrid, Spain; second author: Staff Scientist, Centro de Automática y Robótica, CSIC-UPM, 28500 Arganda del Rey, Madrid, Spain. Corresponding author's E-mail: jose.dorado@ccma.csic.es
}

asexual reproduction in the life cycle of this species. A single Johnsongrass plant can produce 60 to $90 \mathrm{~m}$ of rhizomes in 1 mo (McWhorter 1981). These extensively creeping rhizomes, which regenerate easily when cut into small pieces, are capable of producing highly competitive plants or can remain dormant in a wide range of environmental conditions. Johnsongrass plants that originate from rhizomes are not affected by most of the pre-emergence herbicides used in corn fields. A postemergence herbicide treatment is generally necessary for control but will increase production costs.

Previous studies conducted in corn crops in Spain have indicated a highly aggregated distribution pattern of this species (Andújar et al. 2011). Each of the Johnsongrass patches is generally compact with clearly defined borders. These patches easily can be detected at harvest time because Johnsongrass remains green, but maize plants take on a yellowish color. These features make Johnsongrass an ideal target for site-specific weed management.

There are two major approaches for site-specific weed management: (1) creating a map of weed locations and then controlling an automatic sprayer with the map; and (2) 
detecting and spraying weeds in one operation. Although real-time automatic weed detection and spraying is the focus of considerable research, until now the major approach used has been spraying based on previously constructed maps (Christensen et al. 2009).

The use of map-based patch spraying depends on the availability of reliable data on the spatial distribution of weeds within the fields. Although a wide range of weed detection techniques have been developed over the last $10 \mathrm{yr}$, none of them have reached a wide acceptance. Aerial-based remote sensing can be applied successfully to detect weed patches only when they are relatively large, dense, and uniform, and have unique spectral characteristics (Brown and Noble 2005). A major disadvantage of aerial detection from aircraft or satellites is that images can be difficult to acquire on demand. Ground-based detection using visual evaluations, optoelectronic sensors, or digital cameras, shows more promise for the spatial treatment of small patches (e.g., adjusting the spraying with a nozzle or boom section) and/or when weed size and density are low (Burgos-Artizzu et al. 2009; Christensen et al. 2009; Gerhards and Oebel 2006). However, most of these systems are technologically complex and expensive.

Weed mapping systems using human observation constitute a simple and reliable alternative. Generally, weed detection is based on the fact that flowering structures of weeds penetrate the crop canopy and can be discriminated easily from the crop. Rew et al. (1997) tested a semiautomated system that relied on visual recognition of spikes of various grass weeds in cereal crops from a high-clearance vehicle traveling over the crop tramlines at harvest time. Numerous researchers have used the same approach to map wild oats (Avena fatua $\mathrm{L}$. and A. sterilis $\mathrm{L}$.) from the cabin of combine harvesters (Andújar et al. 2011; Barroso et al. 2005; Colliver et al. 1996; Luschei et al. 2001; Ruiz et al. 2006a,b; Van Wychen et al. 2002).

Two critical issues arise regarding visual weed mapping at harvest time. The first is that the cost associated with weed assessment (Barroso et al. 2005) should be proportional to the economic benefits derived from patch spraying (Forcella 1993). The second issue is the predictive power of these maps. If weed patches are stable between seasons, harvest maps could be used to plan herbicide treatments the following season. If they are not, then the predictive value of these maps might be minimal. Although patch stability depends on the species, some of the key target species for patch treatment, such as common sunflower or cleavers, have been shown to have relatively stable patches (Gerhards et al. 1997; Hamouz et al. 2004; Zhang and Hamill 1998). Although rhizomatous species such as Johnsongrass are expected to be relatively stable in their location, plant densities can change depending on the management practices and environmental conditions present during the growing season.

The objective of this research was to assess the reliability of using maps of Johnsongrass patches constructed at harvest to predict the location of patches in the following cropping season. Furthermore, the long-term stability of these patches was studied in order to determine the temporal limit of these predictions. Economic and environmental factors were considered to evaluate the potential application of this detection system.

\section{Materials and Methods}

Experimental Conditions. The study was conducted from 2005 to 2009 at La Poveda Research Farm (Arganda del Rey, Madrid, Central Spain), in three fields naturally infested with Johnsongrass. The landscape of the site is an alluvial plain in the Jarama River basin with a flat topography. Soils in the three fields have a sandy-loam texture with $39 \%$ sand, $47 \%$ silt, $14 \%$ clay, and $1.4 \%$ organic matter, $\mathrm{N} 0.75 \mathrm{~g} \mathrm{~kg}^{-1}$, $\mathrm{CaCO}_{3} 34 \mathrm{~g} \mathrm{~kg}^{-1}$, and $\mathrm{pH}$ 8.1. Mean daily temperature and annual precipitation during the last $10 \mathrm{yr}$ were $13.5 \mathrm{C}$ and $460 \mathrm{~mm}$, respectively.

Corn was planted all $3 \mathrm{yr}$ in mid-April with $75-\mathrm{cm}$ row spacing and a population of 90,000 plants $\mathrm{ha}^{-1}$. Field A (2.5 ha) was infested heavily with Johnsongrass, fierce thornapple (Datura ferox L.) and cocklebur (Xanthium strumarium L.), with very sparse weed-free areas. In contrast, large portions of Field B (8.3 ha) and Field C (3.4 ha) were almost free of weeds other than Johnsongrass. From 2005 to 2007, a pre-emergence herbicide treatment with atrazine $\left(0.96 \mathrm{~kg}\right.$ ai ha $\left.{ }^{-1}\right)$ plus $S$-metolachlor $\left(0.96 \mathrm{~kg}^{2} \mathrm{hia}^{-1}\right)$ was applied. From 2008, these two herbicides were substituted by isoxaflutol $\left(100 \mathrm{~g}\right.$ ai ha $\left.{ }^{-1}\right)$. Postemergent treatments with nicosulfuron $\left(60 \mathrm{~g}\right.$ ai ha $\left.{ }^{-1}\right)$ were applied at the four- to sixleaf stage of corn in 2005. From 2006 a postemergence treatment with rimsulfuron $\left(60 \mathrm{~g} \mathrm{a} \mathrm{ha}^{-1}\right)$ was applied for the control of Johnsongrass and with thifensulfuron $\left(10 \mathrm{~g}\right.$ ai ha $\left.{ }^{-1}\right)$ for the control of broad-leaved weeds using $200 \mathrm{~L} \mathrm{ha}^{-1}$ of water. Weather conditions during herbicide treatments were adequate, with no wind and warm temperatures. Thereafter, temperatures remained relatively high during the entire growing season with no stress symptoms present. Fertilizers were applied at planting time ( $40 \mathrm{~kg} \mathrm{~N}, 75 \mathrm{~kg} P$ and $75 \mathrm{~kg} \mathrm{~K}$ $\left.\mathrm{ha}^{-1}\right)$ and at the eight-leaf stage $\left(100 \mathrm{~kg} \mathrm{~N} \mathrm{~h}^{-1}\right)$. All of the agricultural operations (plowing, seed drilling, spraying, and combine harvesting) were conducted parallel to the longest side of the fields. The tillage system used included disking the corn stubble in the fall, moldboard plowing during the winter, and one or more preplanting tillage with a field cultivator. Although all these practices favor rhizome displacement, their effects might have been altered by the variable directions of tillage. Sprinkler irrigation was used, with an average of 12 irrigations during 3 mo with a total contribution of $800 \mathrm{~L} \mathrm{~m}^{-2}$. This provided an ample supply of water for crop and weed growth.

Weed Assessment. Johnsongrass patches in Field A were assessed at harvest time during 3 consecutive yr (October 2005, 2006, and 2007) and prior to postemergence herbicide application in the 3 subsequent yr (May 2006, 2007, and 2008). In Field B, fall assessments were conducted in October 2006, 2007, and 2008 and spring assessments in May 2007, 2008, and 2009. In Field C, assessments were carried out in October 2007 and 2008 at harvest time and in May 2008 and 2009 in the spring.

In the fall, presence of Johnsongrass was visually assessed by an observer located in the combine harvester cabin. Johnsongrass plants were easy to identify because they were still green at harvest while corn plants were dry and yellowish. In order to minimize errors, the evaluator remained the same 
for all observations and was previously trained in identifying Johnsongrass patches and in the use of the hardware/software. Johnsongrass patches were relatively homogeneous, and were defined as an area with more than one panicle $\mathrm{m}^{-2}$. Densities below that value were considered scattered plants. This threshold was arbitrarily selected based on the fact that this area is relatively easy to recognize and remember. Data was recorded using a tablet personal computer ${ }^{1}$ with a specific software $^{2}$ designed and developed for this application, and a differential geopositioning system (DGPS) receiver $^{3}$ giving submetric precision. The computer program combined the geoposition provided by the DGPS and the numeric indicator selected for each position (0: absence; 1: presence). Georeferenced points were taken at intervals of $1 \mathrm{sec}$, corresponding to the DGPS frequency, i.e., 1 to $1.2 \mathrm{~m}$ (assuming a maximum speed of $4.5 \mathrm{~km} \mathrm{~h}^{-1}$ for the combine) of separation between neighboring points within the same row and $4.5 \mathrm{~m}$ corresponding to the combine swath width (6 corn rows).

In the spring, at the four-leaf stage of corn, most Johnsongrass plants clearly were visible due to the smaller size of corn plants and to their presence in the wide interrow area. A georeferenced database was generated by an observer equipped with a tablet PC and a DGPS system, using a continuous visual assessment procedure similar to that described previously. The database was created by walking along parallel transects every 6 corn rows $(4.5 \mathrm{~m})$. Georeferenced positions of each assessment were recorded with the same equipment (placed in the backpack of the observer) used at harvest, and using the same numeric indicator to discriminate the absence (less than one plant $\mathrm{m}^{-2}$ ) and presence (more than one plant $\mathrm{m}^{-2}$ ) of Johnsongrass. Because the speed at which the observer walked was similar to the speed of the combine harvester, the fall and spring maps had a similar resolution.

Data Processing and Analysis. Data management and spatial data analysis were carried out using ArcInfo ${ }^{\circledR}$ Geostatistical Analyst. ${ }^{4}$ Preprocessing of data in fall maps was performed in order to remove part of the points with coincident coordinates after projection (two indicator values at the same point) by preserving those with the highest indicator values. This occurred mostly at the beginning/end of the rows and in zones where the combine harvester had to cope with obstacles.

Fall and spring databases were compared to test the similarity of spatial distribution. Observations recorded in fall were interpolated by kriging in order to have comparable continuous estimates with matching points from the spring maps. Due to the binary structure of the data $(0 / 1)$, indicator kriging was used. Exponential and spherical models were used to fit the semivariograms to the data. The interpolated map obtained at harvest was overlaid on the original map of points obtained in the following season resulting in a database with information from both fall and spring. This database stored the georeferenced points of the spring map with the respective value of presence/absence and the associated information for the same coordinate in the interpolated fall map. Cross tables (SPSS 15.0) $)^{5}$ were used to analyze the relationship between both categorical databases. In the "fall database," original values were transformed to a two-category scale according to their probability $(0$ for $\mathrm{P}<0.5 ; 1$ for $\mathrm{P} \geq 0.5)$, whereas the "spring database" consisted of weed presence/absence (0/1) values. In addition, 3- and 5-m buffers were added to the fall maps before creating interpolated maps; kriging then was performed using the above-indicated procedure.

Economic Analysis. The potential economic benefits of patch spraying based on weed distribution maps was assessed by using equation [1], which is adapted to corn from the equation proposed by Ruiz et al. (2006b) for wild oats:

$$
\begin{aligned}
N T=Y\left[1-\frac{Y_{50}}{100} \cdot \frac{A_{50 t}}{100}-\frac{Y_{l}}{100} \cdot \frac{A n t}{100}\right] P- \\
\left.\qquad C m+C t+H\left(D_{1} \cdot \frac{A}{100}+D_{2} \cdot \frac{A_{50}}{100}\right)+C \mathrm{~cm}\right]
\end{aligned}
$$

where $N T$ is the net return per hectare; $Y$ is the corn yield on Johnsongrass-free areas; $Y_{50}$ is the percentage of yield loss at half-rate herbicide in infested areas; $Y_{1}$ is the percentage of yield loss at nontreated infested areas; $A$ is the percentage of the field treated at full-rate; $A_{50 \mathrm{t}}$ is the percentage of infested surface treated at half-rate; $A_{50}$ is the percentage of surface treated at half-rate; $A_{n t}$ is the nontreated infested area; $P$ is the price of corn; $C_{m}$ (only considered in site-specific treatments) is the cost of mapping the field using a $4.5 \mathrm{~m}$ swath combine harvester, which includes the cost of the mapping equipment (DGPS, tablet PC, and software) and the cost of the scout person; $C_{t}$ is the treatment cost with a sprayer with independently controlled sections; $C_{c m}$ is the remaining costs involved in crop production (e.g., seeding, fertilization, tillage, irrigation, pre-emergence herbicide); $H$ is postemergence herbicide cost at full-rate application; and $D_{1}$ and $D_{2}$ are the applied rates (1 and 0.5).

Parameter values used for simulation were: $Y=$ $12,000 \mathrm{~kg} \mathrm{ha}^{-1} ; P=\$ 0.23 \mathrm{~kg}^{-1} ; Y_{50}=7 \% ; Y_{1}=16 \%$ (Barroso, personal communication); $C_{m}=\$ 12.7 \mathrm{ha}^{-1}$ (Ruiz et al. 2006a); $C t=\$ 9.3 \mathrm{ha}^{-1}$ at $3.46 \mathrm{ha} \mathrm{h}^{-1}$ work capacity (Barroso et al. 2004); $C t=\$ 24 \mathrm{ha}^{-1}$ for site-specific spraying of patches and $C t=\$ 29.6 \mathrm{ha}^{-1}$ for a differential-rate spraying (Gerhards and Sökefeld 2003); $C_{c m}=\$ 1,270 \mathrm{ha}^{-1}$; $H=\$ 127 \mathrm{ha}^{-1}$. Actual values for patch densities ranged from 1 to 50 plants $\mathrm{m}^{-2}$, but because individual values were not recorded, $Y_{1}$ and $Y_{50}$ values were estimated, based on our experimental data for a density of 5 plants $\mathrm{m}^{-2}$ (Barroso, unpublished results).

Six herbicide application strategies were simulated: (1) no herbicide; (2) overall full-rate application (standard practice); (3) overall half-rate application; (4) full-rate application to patches recorded in the map generated in the previous fall; (5) half-rate application to patches detected in the previous fall; and (6) full-rate application to patches recorded in the map and half-rate at the rest of the field. Treatment maps were generated using a $6 \mathrm{~m}$ by $6 \mathrm{~m}$ grid, which corresponded to the 6-m width of a section of the sprayer. Due to sampling errors and the displacement of patches from $1 \mathrm{yr}$ to the next, we also have included the economic impact of adding a 3-m buffer to the patches in the three site-specific strategies (numbers 4 to 6).

In order to assess the potential benefits of herbicide applications based on maps from previous years, we calculated 


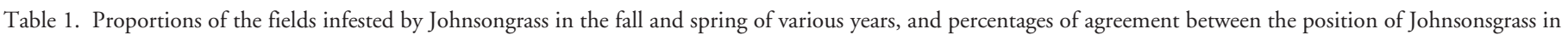

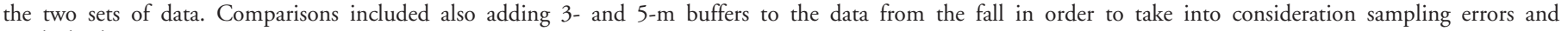
patch displacement.

\begin{tabular}{|c|c|c|c|c|c|c|}
\hline & \multicolumn{2}{|c|}{ Fall vs. Spring } & \multicolumn{2}{|c|}{ Fall $+3 \mathrm{~m}$ vs. Spring } & \multicolumn{2}{|c|}{ Fall $+5 \mathrm{~m}$ vs. Spring } \\
\hline & Infestation & Agreement & Infestation & Agreement & Infestation & Agreement \\
\hline & $\%$ surface & $\%$ & $\%$ surface & $\%$ & $\%$ surface & $\%$ \\
\hline \multicolumn{7}{|l|}{ Field A } \\
\hline $\begin{array}{l}\text { October } 2005 \\
\text { May } 2006\end{array}$ & $\begin{array}{l}26.4 \\
22.6\end{array}$ & 74.9 & $\begin{array}{l}39.4 \\
22.6\end{array}$ & 85.2 & $\begin{array}{l}53.0 \\
22.6\end{array}$ & 91.4 \\
\hline October 2006 & 40.2 & 82.0 & 58.6 & 91.5 & 77.4 & 97.1 \\
\hline May 2007 & 27.8 & & 27.8 & & 27.8 & \\
\hline October 2007 & 40.5 & 82.3 & 49.0 & 85.2 & 72.4 & 96.8 \\
\hline May 2008 & 28.1 & & 28.1 & & 28.1 & \\
\hline \multicolumn{7}{|l|}{ Field B } \\
\hline October 2006 & 19.1 & 57.9 & 28.9 & 72.1 & 34.3 & 78.6 \\
\hline May 2007 & 11.2 & & 11.2 & & 11.2 & \\
\hline October 2007 & 44.9 & 69.8 & 53.2 & 76.9 & 72.4 & 91.5 \\
\hline May 2008 & 48.8 & & 48.8 & & 48.8 & \\
\hline October 2008 & 51.8 & 68.1 & 68.5 & 83.5 & 85.2 & 95.5 \\
\hline May 2009 & 60.4 & & 60.4 & & 60.4 & \\
\hline \multicolumn{7}{|l|}{ Field C } \\
\hline October 2007 & 21.8 & 72.6 & 25.0 & 73.8 & 43.0 & 90.1 \\
\hline May 2008 & 20.0 & & 20.0 & & 20.0 & \\
\hline October 2008 & 33.5 & 59.5 & 49.0 & 75.4 & 68.1 & 92.1 \\
\hline May 2009 & 38.2 & & 38.2 & & 38.2 & \\
\hline Average & & 70.9 & & 80.4 & & 91.6 \\
\hline
\end{tabular}

the net returns of the site-specific strategies in different years based on data from 1, 2, or 3 yr. The potential herbicide reduction derived from the different simulated site-specific strategies was calculated based on relation to an overall treatment at full dose.

\section{Results and Discussion}

Fall vs. Spring Maps. Visual assessment of Johnsongrass patches carried out from the combine in autumn were relatively simple and yielded a high volume of georeferenced data. A total of 225,717 observations with presence/absence of Johnsongrass were recorded. The proportion of the fields infested by this weed ranged from $19.1 \%$ to $51.8 \%$, with an average of $34.8 \%$. Similarly, spring assessments showed infestation levels from $11.2 \%$ to $60.4 \%$, with an average of $32.1 \%$ (Table 1).

The percentage of agreement between the position of Johnsongrass patches on the two maps (fall vs. spring) was on average $71 \%$ (Table 1$)$. The highest agreement $(82 \%)$ was obtained in two cases with relatively large infestation levels ( $40 \%$ in fall), whereas the lowest agreement $(58 \%)$ was obtained when the infested area was smallest (19\% in fall). In general, the largest differences between the two maps were found in zones of recent patch expansion or with new patches.

Adding $3 \mathrm{~m}$ and $5 \mathrm{~m}$ buffers to the patches detected at harvest substantially increased the area considered to be infested. The average increases in area were $11.7 \%$ and $28.4 \%$ for the 3 and $5 \mathrm{~m}$ buffers, respectively (Table 1 ). As expected, adding these "insurance" zones increased the agreement between infested areas in fall and spring to $80.4 \%$ and $91.6 \%$ when using 3 and $5 \mathrm{~m}$ buffers, respectively. The implementation of buffer zones around the weed patches has been recommended to encompass movements on weed populations and possible mapping errors (Rew et al. 1997). However, using buffers lead to a substantial increase in the sprayed area (Barroso et al. 2004).

Although our study only considered the use of harvest maps to make prescription maps for postemergence herbicide applications, it also is possible to use harvest maps for planning preplanting treatments. Because a proportion of Johnsongrass population can emerge prior to seeding, emerged patches could be destroyed site-specifically with a nonselective herbicide. The potential of pre-emergence patch spraying is minimal due to the very low control of this species by most of the pre-emergence herbicides available in the Spanish market.

Temporal Stability of Patches. Although the relative positions of the original patches remained almost unchanged from $1 \mathrm{yr}$ to the next, the area infested by Johnsongrass increased in all the fields during the experimental period (Table 1), due to the expansion of existing patches and to new patches created by the dispersion of rhizomes by tillage. In field $A$, the proportion of the field infested in the fall of the first year was about $26 \%$, increasing to over $40 \%$ in the next 2 yr. In field B, an initial infestation of about $19 \%$ increased to an area above $45 \%$ over the next 2 yr. In field C, the area infested increased from about $22 \%$ to $33 \%$ in $1 \mathrm{yr}$. Although this expansion might be surprising, considering that the fields were treated with specific herbicides for Johnsongrass control, other studies conducted in the same site and under similar conditions have indicated that control levels obtained with these herbicides frequently were below 
Table 2. Percentages of agreement between the position of Johnsongrass patches in the fall and their respective position in the spring 2 and 3 yr later.

\begin{tabular}{|c|c|c|c|}
\hline & Fall vs. Spring & $\begin{array}{c}\text { Fall }+3 \mathrm{~m} \text { vs. } \\
\text { Spring }\end{array}$ & $\begin{array}{c}\text { Fall }+5 \mathrm{~m} \text { vs. } \\
\text { Spring }\end{array}$ \\
\hline & & Agreement (\%) & \\
\hline \multicolumn{4}{|l|}{ Comparison after 2 yr } \\
\hline \multicolumn{4}{|l|}{ Field A } \\
\hline $\begin{array}{c}\text { vs. May } 2007 \\
\text { October } 2006\end{array}$ & 48.9 & 62.9 & 74.8 \\
\hline vs. May 2008 & 69.5 & 79.1 & 89.9 \\
\hline \multicolumn{4}{|l|}{ Field B } \\
\hline $\begin{array}{l}\text { October } 2006 \\
\text { vs. May } 2008\end{array}$ & 46.0 & 49.1 & 68.1 \\
\hline $\begin{array}{l}\text { October } 2007 \\
\text { vs. May } 2009\end{array}$ & 59.8 & 82.7 & 95.3 \\
\hline \multicolumn{4}{|l|}{ Field C } \\
\hline vs. May 2009 & 40.8 & 47.7 & 74.3 \\
\hline Average & 53.0 & 64.3 & 80.5 \\
\hline \multicolumn{4}{|l|}{ Comparison after 3 yr } \\
\hline $\begin{array}{l}\text { Field A } \\
\text { October } 2005 \\
\text { vs. May } 2008\end{array}$ & 41.5 & 54.9 & 68.1 \\
\hline \multicolumn{4}{|l|}{ Field B } \\
\hline vs. May 2009 & 23.9 & 34.9 & 64.8 \\
\hline Average & 32.7 & 44.9 & 66.5 \\
\hline
\end{tabular}

$80 \%$ (Barroso, personal communication). Weed escapes from these treatments are able to perpetuate or even to expand Johnsongrass infestations, particularly under a continuous corn regime. Although this cropping system clearly is undesirable from the point of view of Johnsongrass management, economic reasons make this the prevailing cropping system in irrigated lands of Central Spain. A survey conducted in three corn-growing regions of Spain showed that the percentage of field area infested by Johnsongrass was four to eight times higher in Central Spain than in other regions where corn was rotated with other crops (Andújar et al. 2011).

The degree of agreement between the position of the patches found in the fall and the position of these patches in the spring 2 yr later decreased to $53 \%$. Moreover, the degree of agreement with the positions 3 yr later (comparison made only in the fields A and B) was only 33\% (Table 2). By adding $3 \mathrm{~m}$ buffers to the original patches it was possible to increase the percentages of agreement in the position of patches up to $64 \%$ and $45 \%$ for 2 - and 3-yr periods, respectively. Adding $5 \mathrm{~m}$ buffers increased these percentages up to 81 and $67 \%$ for 2 and $3 \mathrm{yr}$, respectively (Table 2 ).

Due to the rhizomatous expansion of this weed, patch growth is relatively predictable. Previous studies have shown that patch growth takes place in the direction of tillage, with little displacement in the opposite direction and both sides (Andújar, unpublished data). Although abundant seed production was observed in the infested area, a very low number of Johnsongrass seedlings were detected inside the patches, and practically no seedlings were found outside these areas. Studies carried out in Argentina show that although sexual and asexual reproductions occur simultaneously, and in spite of the large annual inputs of seeds, the soil seed bank is maintained at low levels due to heavy predation (Scopel et al. 1988). This could explain the predominant clonal growth of Johnsongrass populations. In addition, emerged seedlings are less competitive with the crop and are more sensitive to most herbicides. Apparently, the only significant role played by seeds may be the long-range dispersal caused by combine harvesters (Ghersa et al. 1993).

Economic Analysis. According to our estimates, the highest net returns could be obtained by spraying full rates of herbicides to patches recorded in the map generated in the previous fall, which improved net returns $1.4 \%$ over the no spray treatment (Table 3). Previous studies suggested that this strategy was more profitable on fields with lower infestation levels (Barroso et al. 2004; Luschei et al. 2001) and with higher patchiness (Oriade et al. 1996). Spraying the full- or half-rate over the entire field area resulted in slightly lower returns. Spraying the full herbicide rate on infested areas and half rates in the rest of the field resulted in the lowest net returns. Adding a 3-m buffer to the infested area detected the previous fall increased the net returns, reaching levels similar to the most profitable strategy (Table 3). Adding a $5 \mathrm{~m}$ buffer did not result in any significant improvement (data not shown). Although the economic differences among strategies were not significant, the herbicide reduction potential of site-specific strategies could lead to increased interest in these techniques in three different scenarios: (1) if one of the farmer's objectives is to reduce herbicide residues in food; (2) if herbicide prices increase; or (3) if government regulations promote a reduction in the usage of agricultural pesticides.

The economic feasibility of planning herbicide treatments based on weed maps is conditioned by patch stability. If location and density of weed patches remains consistent over time, maps from one year could be used to plan herbicide application in subsequent years. Our simulation showed that using maps obtained in the fall to predict the position of Johnsongrass patches 2 or 3 yr later resulted in a decrease of economic benefits compared with the strategy based on maps obtained the previous year. In the specific case of patch spraying the full rate of herbicide, net returns obtained by using maps generated 2 and $3 \mathrm{yr}$ in advance were reduced by $2.2 \%\left(\$ 29 \mathrm{ha}^{-1}\right)$ and $4.6 \%\left(\$ 62 \mathrm{ha}^{-1}\right)$, respectively (Table 3). This is consistent with a study by Colbach et al. (2000) who, working with an annual grass, concluded that although data from one season could be used to predict forward into the following season, longer predictions were too inaccurate.

Herbicide Volume Reduction. Spraying full rates of herbicides to Johnsongrass patches mapped during the previous fall resulted in an average $65 \%$ reduction in the volume of herbicide applied to control this weed (Table 4). This reduction was even larger $(83 \%)$ when the patches were sprayed with half rates of herbicides. Using a low-risk strategy based on applying full rates to the detected patches and half rates to the rest of the field resulted only in a $33 \%$ of herbicide volume reduction. Using a 3-m buffer around the detected 


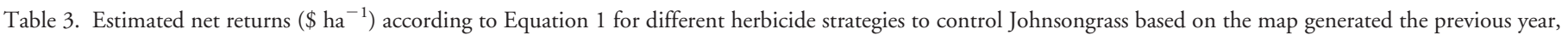

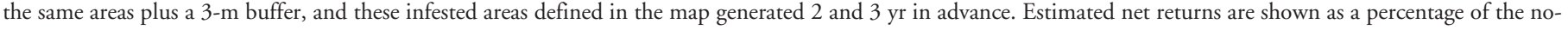
spray treatment.

\begin{tabular}{|c|c|c|c|c|c|c|c|c|c|}
\hline \multirow[b]{3}{*}{ Herbicide strategy based on: } & \multicolumn{9}{|c|}{ Estimated net returns } \\
\hline & \multicolumn{3}{|c|}{ Field A } & \multicolumn{3}{|c|}{ Field B } & \multicolumn{2}{|c|}{ Field C } & \multirow[b]{2}{*}{ Average } \\
\hline & 2006 & 2007 & 2008 & 2007 & 2008 & 2009 & 2008 & 2009 & \\
\hline No spray $\left(\$\right.$ ha $\left.^{-1}\right)$ & 1,390 & 1,367 & 1,366 & 1,440 & 1,275 & 1,223 & 1,402 & 1,321 & 1,348 \\
\hline Overall, $1 \times$ rate $(\%)$ & 97.4 & 99.0 & 99.1 & 94.0 & 106.2 & 110.7 & 110.7 & 102.5 & 100.4 \\
\hline Overall, $0.5 \times$ rate $(\%)$ & 98.8 & 99.7 & 99.8 & 96.9 & 103.8 & 106.3 & 106.0 & 101.7 & 100.5 \\
\hline \multicolumn{10}{|l|}{ Map of the previous year } \\
\hline Site-specific, $1 \times$ rate $(\%)$ & 100.3 & 101.0 & 101.0 & 97.8 & 104.4 & 106.5 & 101.0 & 101.5 & 101.4 \\
\hline Site-specific, $0.5 \times$ rate $(\%)$ & 99.2 & 99.6 & 99.6 & 97.8 & 101.5 & 102.7 & 99.2 & 99.9 & 99.8 \\
\hline Site-specific, $1 \times-0.5 \times$ rate $(\%)$ & 97.6 & 98.7 & 98.7 & 94.7 & 104.1 & 107.4 & 97.6 & 100.9 & 99.7 \\
\hline \multicolumn{10}{|l|}{ Map of previous year $+3 m$ buffer } \\
\hline Site-specific, $1 \times$ rate $(\%)$ & 99.8 & 100.0 & 100.3 & 97.3 & 104.3 & 107.6 & 99.8 & 101.7 & 101.2 \\
\hline Site-specific, $0.5 \times$ rate $(\%)$ & 98.9 & 99.1 & 99.2 & 97.5 & 101.3 & 103.2 & 99.2 & 99.9 & 99.6 \\
\hline Site-specific, $1 \times-0.5 \times$ rate $(\%)$ & 97.3 & 98.2 & 98.5 & 94.4 & 104.2 & 108.0 & 97.3 & 101.0 & 99.6 \\
\hline \multicolumn{10}{|l|}{ Map of 2 yr earlier } \\
\hline Site-specific, $1 \times$ rate $(\%)$ & - & 99.3 & 99.9 & - & 103.0 & 105.2 & - & 100.4 & 97.8 \\
\hline Site-specific, $1 \times$ rate $+3 \mathrm{~m}$ buffer $(\%)$ & - & 99.3 & 99.1 & - & 103.5 & 109.5 & - & 100.9 & 99.4 \\
\hline \multicolumn{10}{|l|}{ Map of 3 yr earlier } \\
\hline Site-specific, $1 \times$ rate $(\%)$ & - & - & 98.6 & - & - & 100.2 & - & - & 95.4 \\
\hline Site-specific, $1 \times$ rate $+3 \mathrm{~m}$ buffer $(\%)$ & - & - & 98.6 & - & - & 101.6 & - & - & 96.1 \\
\hline
\end{tabular}

patches increased the area to be treated and significantly reduced the herbicide reduction obtained with the three sitespecific strategies (Table 4).

Although the largest herbicide reductions were obtained with site-specific application at half-rates of herbicides, this strategy involves considerable risks. Various authors have shown that low rates of herbicides can increase the risk of control failure under adverse environmental conditions and under high weed densities (Belles et al. 2000; Zhang et al. 2000). Furthermore, in patch-spraying systems, there is a higher chance of reinfestation from isolated plants present outside the patches (or not detected) and, consequently, not treated in the previous year.

Herbicide volume reduction differed substantially between fields and between years in the same field. Our simulation showed that spraying patches with the full rate of herbicide in field B resulted in $81 \%$ herbicide reduction in 2007 (with
$19 \%$ of the field infested) and only $48 \%$ in 2009 (with $52 \%$ of the field infested). In general, the highest reductions were obtained in field C, with the lowest levels of infestation (average 29\%), whereas the lowest reductions were obtained in field B, with the highest levels of infestation (average 39\%). Thus, herbicide reductions were inversely proportional to the infested area in the field.

Previous studies have reported herbicide reductions resulting from patch spraying higher than $75 \%$ in corn crops infested with grass weeds (Gerhards and Christensen 2003; Timmermann et al. 2003). In winter cereals, reported reductions reached up to $74 \%$ when herbicide rates were adjusted to the densities of wild oats present in different zones of the fields (Ruiz et al. 2006a). All these results indicate the possibility of obtaining an environmental benefit by using site-specific weed management technologies, which can contribute significantly to preserve environmental quality by minimizing the use of herbicides.

Table 4. Estimated herbicide volume reduction (\%) for the three site-specific herbicide application strategies to control Johnsongrass. In the simulations, the treatments were applied to the infested areas defined in the map generated the previous year only, or to the same areas plus a $3 \mathrm{~m}$ buffer.

\begin{tabular}{|c|c|c|c|c|c|c|c|c|c|}
\hline \multirow[b]{3}{*}{ Herbicide strategy based on: } & \multicolumn{9}{|c|}{ Estimated herbicide volume reduction (\%) } \\
\hline & \multicolumn{3}{|c|}{ Field A } & \multicolumn{3}{|c|}{ Field B } & \multicolumn{2}{|c|}{ Field C } & \multirow[b]{2}{*}{ Average } \\
\hline & 2006 & 2007 & 2008 & 2007 & 2008 & 2009 & 2008 & 2009 & \\
\hline \multicolumn{10}{|l|}{ Map of the previous year } \\
\hline Site-specific, $1 \times$ rate & 74 & 60 & 60 & 81 & 55 & 48 & 78 & 67 & 65 \\
\hline Site-specific, $0.5 \times$ rate & 87 & 80 & 80 & 90 & 78 & 74 & 89 & 83 & 83 \\
\hline Site-specific, $1 \times-0.5 \times$ rate & 37 & 30 & 30 & 40 & 28 & 24 & 39 & 33 & 33 \\
\hline Site-specific, $1 \times$ rate & 61 & 41 & 51 & 71 & 47 & 31 & 75 & 51 & 54 \\
\hline Site-specific, $0.5 \times$ rate & 80 & 71 & 75 & 86 & 73 & 66 & 87 & 76 & 77 \\
\hline Site-specific, $1 \times-0.5 \times$ rate & 30 & 21 & 25 & 36 & 23 & 26 & 27 & 26 & 27 \\
\hline
\end{tabular}




\section{Sources of Materials}

${ }^{1}$ Tablet computer, Stylistic 2300, Fujitsu Personal System, Santa Clara, CA.

${ }^{2}$ Software, Real-time system for acquiring georeferenced visual assessments. System developed at Instituto de Automática Industrial (now Centro de Automática y Robótica), Spain.

${ }^{3}$ Differential geopositioning system receiver, Hemisphere Crescent R130 DGPS with Omnistar differential correction, Hemisphere GPS Inc. Calgary, AB.

${ }^{4}$ ArcInfo ${ }^{\circledR}$ 9.2, ESRI, Redlands, CA.

${ }^{5}$ SPSS 15.0 (Statistical Product and Service Solutions), SPSS, Chicago, IL.

\section{Literature Cited}

Andújar, D., D. Ruiz, A. Ribeiro, C. Fernández-Quintanilla, and J. Dorado. 2011. Spatial distribution patterns of Johnsongrass (Sorghum halepense) in corn fields in Spain. Weed Sci. 59:82-89.

Barroso, J., C. Fernández-Quintanilla, B. D. Maxwell, and L. J. Rew. 2004 Simulating the effects of weed spatial pattern and resolution of mapping and spraying on economics of site-specific management. Weed Res. 44:460468.

Barroso, J., D. Ruiz, C. Fernández-Quintanilla, E. S. Leguizamon, P. Hernaiz, A. Ribeiro, B. Diaz, B. D. Maxwell, and L. J. Rew. 2005. Comparison of sampling methodologies for site-specific management of Avena sterilis. Weed Res. 45:165-174.

Belles, D. S., D. C. Thill, and B. Shafii. 2000. PP-604 rate and Avena fatua density effects on seed production and viability in Hordeum vulgare. Weed Sci. 48:378-384.

Bendixen, L. E. 1986. Corn (Zea mays) yield in relationship to Johnsongrass (Sorghum halepense) population. Weed Sci. 34:449-451.

Brown, R. B. and S. D. Noble. 2005. Site-specific weed management: sensing requirements—what do we need to see? Weed Sci. 53:252-258

Burgos-Artizzu, X. P., A. Ribeiro, A. Tellaeche, G. Pajares, and C. FernándezQuintanilla. 2009. Improving weed pressure assessment using digital images from an experience-based reasoning approach. Comput. Electron. Agric. 65:176-185.

Christensen, S., H. T. Sagaard, P. Kudsk, M. Norrenmark, I. Lund, E. S. Nadini, and R. Jorgensen. 2009. Site-specific weed control technologies. Weed Res. 49:233-241.

Colbach, N., F. Forcella, and G. A. Johnson. 2000. Spatial and temporal stability of weed populations over five years. Weed Sci. 48:366-377.

Colliver, C. T., B. D. Maxwell, D. A. Tyler, D. W. Roberts, and D. S. Long. 1996. Georeferencing wild oat infestations in small grains: accuracy and efficiency of three weed survey techniques. Pages 453-463 in P. C. Robert, R. H. Rust, and W. E. Larson, eds. Proceedings of the 3rd International Conference on Precision Agriculture, Minneapolis, MN. Madison, WI: American Society of Agronomy.

Forcella, F. 1993. Value of managing within-field variability. Pages 125-132 in P. C. Robert, R. H. Rust, and W. E. Larson, eds. Proceedings of Soil Specific Crop Management Management: A Workshop on Research and Development Issues, Minneapolis, MA. Madison, WI: American Society of Agronomy.
Gerhards, R. and S. Christensen. 2003. Real-time weed detection, decision making and patch spraying in maize, sugarbeet, winter wheat and winter barley. Weed Res. 43:385-392.

Gerhards, R. and H. Oebel. 2006. Practical experiences with a system for sitespecific weed control in arable crops using real-time image analysis and GPScontrolled patch spraying. Weed Res. 46:185-193.

Gerhards, R. and M. Sökefeld. 2003. Precision farming in weed control—system components and economic benefits. Pages 229-234 in J. V. Staffoard and A. Werner, eds. Proceedings of 4th European Conference on Precision Agriculture, Berlin, Germany. Wageningen, the Netherlands: Wageningen Academic.

Gerhards, R., D. Y. Wyse-Pester, D. Mortensen, and G. A. Johnson. 1997. Characterizing spatial stability of weed populations using interpolated maps. Weed Sci. 45:108-119.

Ghersa, C. M., M. A. Martinez-Ghersa, E. H. Satorre, M. L. Van Esso, and G. Chichotky. 1993. Seed dispersal, distribution and recruitment of seedlings of Sorghum halepense (L.) Pers. Weed Res. 33:79-88.

Hamouz, P., J. Soukup, J. Holec, and M. Jursik. 2004. Field-scale variability of weediness on arable land. Plant Soil Environ. 50:134-140.

Holm, L. G., D. L. Plucknett, J. V. Pancho, and J. P. Herberger. 1977. The World's Worst Weeds. Distribution and Biology. Honolulu, HI: University Press of Hawaii. 609 p.

Luschei, E. C., L. R. Van Wychen, B. D. Maxwell, A. J. Bussan, D. Buschena, and D. Goodman. 2001. Implementing and conducting on-farm weed research with the use of GPS. Weed Sci. 49:536-542.

McWorther, C. 1981. Johnson grass as a weed. USDA Farmers' Bull. 1537:3-19.

Mitskas, M. B., C. E. Tsolis, I. G. Eleftherohorinos, and C. A. Damalas. 2003. Interference between corn and Johnsongrass (Sorghum halepense) from seed or rhizomes. Weed Sci. 51:540-545.

Oriade, C. A., R. P. King, F. Forcella, and J. L Gunsolus. 1996. A bioeconomic analysis of site-specific management for weed control. Rev. Agric. Econ. 18:523-535.

Rew, L. J., P.C.H. Miller, and M.E.R. Paice. 1997. The importance of patch mapping resolution for sprayer control. Aspect Appl. Biol. 48:49-55.

Ruiz, D., C. Escribano, and C. Fernández-Quintanilla. 2006a. Assessing the opportunity for site-specific management of Avena sterilis in winter barley fields in Spain. Weed Res. 46:379-387.

Ruiz, D., C. Escribano, and C. Fernández-Quintanilla. 2006b. Identifying associations among sterile oat (Avena sterilis) infestation level, landscape characteristics, and crop yields. Weed Sci. 54:1113-1121.

Scopel, A. I., C. L. Ballare, and C. M. Ghersa. 1988. The role of seed reproduction in the population ecology of Sorghum halepense (L.) Pers. in maize crops. J. Appl. Ecol. 25:951-962.

Timmermann, C., R. Gerhards, and W. Kühbauch. 2003. The economic impact of site-specific weed control. Precis. Agric. 4:249-260.

Van Wychen, L. R., E. C. Luschei, A. J. Bussan, and B. D. Maxwell. 2002. Accuracy and cost effectiveness of GPS-assisted wild oat mapping in spring cereal crops. Weed Sci. 50:120-129.

Warwick, S. and L. Black. 1983. The biology of Canadian weeds-Sorghum halepense. Can. J. Plant Sci. 63:997-1014.

Zhang, J. H. and A. S. Hamill. 1998. Temporal and spatial distributions of velvetleaf seedlings after 1 year's seeding. Weed Sci. 46:414-418.

Zhang, J., S. E. Weaver, and A. S. Hamill. 2000. Risks and reliability of using herbicides at below-labeled rates. Weed Technol. 14:106-115.

Received June 21, 2010, and approved April 27, 2011. 